\title{
ДОМИНАНТНЕ ВРЕДНОСНЕ ОРИЈЕНТАЦИЈЕ И ФАКТОРИ ВРЕДНОСНОГ УСМЕРАВАҢА МЛАДИХ
}

\author{
Бисера С. Јевтић ${ }^{1}$ \\ Универзитет у Нишу, Филозофски факултет, Департман за педагогију \\ Александра С. Јовановић \\ Универзитет у Нишу, Филозофски факултет, Департман за педагогију \\ (студент ДАС)
}

\begin{abstract}
Ancmpaкm: Циљ рада је да укаже на дескрипторе вредносних система који постоје у друштву, како у Србији тако и у другим земљама. Анализом резултата истраживања и педагошких импликација аутора широм света, желе се приближити погледи на морал и вредности, првенствено код ученика. Жели се испитати које вредности доминирају, односно какви су животни стилови савременог друштва. Дискусијом о моралу, вредностима, даје се сажет приказ вредносних преференција. Закључује се да преовладавају исте универзалне вредности. Заступљен је вредносни плурализам. Породица је најважнија вредност у животима људи. Школа је институција моралног и вредносног усмеравања у којој треба потенцирати однос међусобног поштовања. Тежња ка алтруизму и волонтеризму одраз је позитивних ставова и жеље да се другима помогне. Медији имају значајну улогу у формирању вредности и потребно је користити њихову образовну функцију. Слободно време је значајан сегмент у коме се може деловати на формирање вредности и потребно је организовати га с циљем сопственог развоја.
\end{abstract}

Кључне речи: вредности, вредносне оријентащије, морално васпитање, фактори вредносног усмеравања

\section{Увод}

Вредности су саставни део човековог живота. Скуп вредности чини вредносни систем индивидуе, а самим тим и његов морал, односно поглед на свет. Морал, односно морално исправно мишљење се учи, па самим тим зависи и разликује се од културе. Морал у себи обухвата одређене вредности које га обликују. Васпитни поступци доводе до пожељног моралног понашања, али неретко од саме индивидуе зависи шта ће перципирати као морално добро, као

\footnotetext{
${ }^{1}$ bisera.jevtic@filfak.ni.ac.rs
} 
и каквим ће вредностима тежити у животу. Много фактора доводи до перципирања одређених вредности као изузетно важне и најмање важне, као и живот у складу са њима. Саме вредносне преференције могу утицати на све сфере друштвеног живота појединца. Школа, породица, слободно време, медији утичу на морално и вредносно усмеравање али су и одраз вредности друштва.

Морално понашање зависи од стадијума моралног развоја на коме се појединац налази, а стадијуми развоја прелазе се постепено кроз сазревање. У складу са моралним резоновањем, особа се понаша на друштвено прихватљив или неприхватљив начин. Међутим, само морално резоновање да је нешто добро или лоше не подразумева одређене вредности којима се окрећемо и које преферирамо као животни стил. Такође, одређене вредности не значе ни одређено понашање уколико се понашамо само онако како то други од нас очекују, односно нисмо достигли неке више стадијуме моралног развоја, када имамо своје вредносне принципе а истовремено разумемо и поштујемо туђе. Когнитивно, афективно и психомоторно подручје развоја, породица, школа и окружење, утичу на наше морално понашање (Jevtić, 2012).

Често се не прави дистинкција између дефинисања појмова вредности и вредносне оријентације, тако их Хавелка (1998) сврстава у индивидуалне и социјалне циљеве којима појединац тежи. Људи у животу не теже само једној вредности, али могу се оријентисати око одређених вредности које су у садејству. Често коришћена типологија вредности јесте Шварцова (Schwartz) подела на: управљање собом, стимулација/покретачи, хедонизам, постигнуће, моћ, сигурност, конформизам, традиција, добробит, универзализам/разумевање (Schwartz, 2012: 5-7). Према Шварцу вредности можемо посматрати у њиховој повезаности, односно искључивању. Тако неке вредности посматрамо у садејству: моћ и постигнуће; постигнуће и хедонизам; хедонизам и стимулација; стимулација и самоусмеравање; самоусмеравање и универзализам; универзализам и добронамерност; добронамерност и традиција; добронамерност и конформизам; конформизам и традиција; традиција и сигурност; конформизам и сигурност; сигурност и моћ (Schwartz, 2012: 9-10). Шварц наводи да постоји тенденција истог сукоба и подударања вредности у друштвима, па тако моћ, постигнуће, хедонизам, стимулација, самоусмеравање регулишу наше персоналне карактеристике, док добронамерност, универзализам, традиција, конформизам, сигурност регулишу како се односимо према другима. Моћ и постигнуће део су самопобољшања, хедонизам, стимулација и самоусмеравање део су отворености за промене, очување осликава сигурност, конформизам и традиција, док универзализам и добронамерност осликавају самотрансценденцију (Schwartz, 2012: 13).

У раду износимо налазе истраживања и погледе на доминантне вредности, односно највише и најмање цењене вредности у друштву. Имплицирамо да школа, односно морално образовање, квалитетно организовање слободног времена у коме је потребно бавити се волонтеризмом и бити физички активан, коришћење образовне функције медија позитивно вредносно усмеравају сваког појединца. 


\section{1. Налази истраживања о преферираним вредностима ученика и одраслих}

Вредносне оријентације као и њихов утицај на одређене сфере живота и личност појединца заокупљују пажњу многих аутора. Реализована су многа истраживања која су вредносне преференције, али и утицаје на формирање вредности, мерила укрштањем различитих варијабли и употребом различитих мерних инструмената. Скуп свих резултата може указати на постојање, односно доминацију одређених моралних вредности у одређеном друштву, односно култури. „Социјална карактеристика личности зависи управо од вредносних оријентација“ (Đorđević, 2002: 42). Друштво обликује појединца, али уколико полазимо од сентенце да вредности једног човека могу обликовати вредности групе, а самим тим и друштва, несумњиво је важно каквим вредностима људи данас теже. Анализа вредносног система широм света даје слику општеприхваћених вредности данас, као и њихов утицај на активности појединца.

Основношколски узраст је специфичан када су у питању вредности, што се може објаснити недовољном зрелошћу испитаника да дају адекватне одговоре, који се неће променити за неколико година (Budimir-Ninković, 2008). Истичући адолесцентни период као транзиторни, тежи се открити које то вредности преферирају млади. Истраживање спроведено над хиљаду адолесцената, на узрасту од шеснаест година, показало је да су самоактуализација, хедонизам, успостављање социјалних контаката најважније вредности. Испитанице више теже самоактуелизацији и алтруизму, а припадници мушког пола више цене популарност, традицију, престиж (Petrović i Zotović, 2012). Јоксимовић и Максић (2006) у свом истраживању спроведеном 2003. године над 628 ученика првог разреда средње школе су закључиле да је утилитаризам, односно бављење послом који је добро плаћен највише вреднован, као и да су алтруистичнија деца родитеља са основношколским образовањем. Мерење алтруизма и моралности на узорку око 1.200 адолесцената у Републици Српској показало је да је мушки пол алтруистичнији и да је на вишем ступњу моралности од женског пола. Показало се да испитаници који имају пријатеље друге нације испољавају виши степен алтруизма (Čekrlija i sar., 2004).

Међу 2.426 анкетираних средњошколаца Србије, 2007. године, показало се да се највише цени пријатељство, партнерска љубав, материјални стандард и самосталност. Најмање се цени моћ, ауторитет, популарност, друштвено ангажовање, постигнуће (Kuzmanović i Petrović, 2009). Истраживање спроведено 1998. године у Хрватској међу средњошколцима показало је да се највише вреднује здравље, а затим пријатељство. Испитаницима је било најважније да воле и буду вољени, а најмању важност придавали су моћи и утицају на друге људе. Оријентисали су се ка самоостварењу, а најмање ка хедонизму (Franc i sar., 2002). Испитаници узраста од 18 година највећу вредност придају традицији а најмање моћи (Dević i sar., 2015). Компарцијом истраживачких налаза од 1986. до 2013. године о вредностима у Хрватској над испитаницима од 
15 до 30 година живота показало се да је данашња генерација младих више окренута свету око себе, пријатељствима, социјалним односима, образовању, усавршавању, вери, послу, а смањен је интерес за политику и забаву (Ilišin i Gvozdanović, 2016: 182). С обзиром да вредности којима тежимо обликују наш живот и утичу на наше активности, може се очекивати да ће особе одређених стилова живота тежити одређеним вредностима и обрнуто.

Истраживање вредносних оријентација и преференција животних стилова на узорку од 463 адолесцента старости 17 и 18 година, из Новог Сада, спроведено 1998. године показало је да се највише вредновала приватна својина, неегалитаризам, отвореност према свету, равноправност полова, општи активизам, неконформизам, неауторитарност и друштвени пасивизам, те да се резултати овог истраживања поклапају са резултатима истраживања спроведених 1994. године, што је показало да су вредности стабилне. Највише преферирани животни стилови адолесцената били су утилитарни, породично-сентиментални, хедонистички, односно адолесценти су високо ценили проналазак посла који ће им обезбедити живот, формирање породице са драгом особом, уживање, и у односу на раније истраживање хедонизам је више цењен него знање. Најмање популарни стилови живота су прометејски активизам/борба за правду, оријентација на моћ и оријентација на популарност (Mladenović i Knebl, 2000).

На узорку од 509 адолесцента испитивале су се вредносне оријентације у контексту опредељености за будуће занимање, особина личности и породичног живота. У контексту будућег занимања испитаницима су најзначајније вредности сигурност, сарадња, пријатност, усавршавање и самосталност, док су утицајност и популарност најмање важне. У контексту личних особина доминирају пријатност, усавршавање, сарадња, сигурност и самосталност. Религиозност и популарност су најмање важне као личне особине. У контексту породичног живота најпожељније су сарадња, сигурност, усавршавање, пријатност, док популарност и религиозност имају најниже процене. Када су у питању сва три контекста посматрана заједно, на средњем нивоу значајности налазе се помагање, праведност, зарада, сазнање и утицајност (Havelka, 1998). Потребно је поново испитати да ли су ове вредности заступљене и данас.

Истраживање спроведено 2004. године над 3.639 испитаника имало је за циљ да утврди да ли су још увек заступљене традиционалне вредности. Традиционализам је сагледаван кроз колективизам, ауторитаризам и патријархалну оријентацију. Испитаници су били узраста од 18 до преко 60 година старости, а резултати су упоређени са истраживањем спроведеним 1989. године над 4.352 испитаника. Резултати су показали да не постоје значајне разлике у односу на 1989. годину. Код испитаника доминира колективизам, насупрот индивидуализму, односно испитанци се окрећу заједништву „чак и када то систем и институције више не подржавају“ (Реšić, 2006: 298). Показало се да је изразита ауторитарност више била заступљена раније него данас, али такође да је дошло и до пада вредности као што је изразита неауторитарност. Када је у питању патријархална оријентација, изразита патријархалност се смањила и повећала се непатријархална оријентација (Реšić, 2006). 
У истраживању ауторке Радоман (2011) показало се да око 30\% средњошколаца у Србији (N=630) има традиционалне ставове, али преко 20\% испитаника има нетрадиционалне ставове и умерене ставове. Истраживње ЦеСИД-а (Javno mnjenje Srbije - politički aktivizam građana Srbije, 2017) показало је да се млади више окрећу породичним вредностима него друштвеним вредностима. Преко 60\% од 1.000 анкетираних грађана, старијих од 18 година, не прати политичка дешавања. Важнији су им проблеми који настају у породици него друштвени активизам.

Истраживање аутора Дуњић-Мандић и Каранац (2017) показало је да су код ученика гимназије десет највише цењених вредности, односно друштвених циљева: запосленост, материјални стандард, наука и култура, стабилна држава, сигурност и безбедност, хумани односи, социјална једнакост, еколошки циљеви, демократија, одбрана земље (Dunjić-Mandić i Karanac, 2017: 471).

Вредновање здравог живота, вођење здравог и умереног живота, бављење спортом, неки истраживачи довели су у везу са вредносним преференцијама. Истраживање на узорку од 8.000 младих, узраста од 15 до 29 година у Мађарској, показало је да физички активни и неактивни млади имају исте вредносне преференције, али им нису подједнако важне исте вредности. Вредности према којима показују исте преференције јесу: породична сигурност, мир, традиција, љубав, лепота, религија, унутрашњи мир, друштвено уређење. Млади који се баве активно спортом више вреднују искрено пријатељство, креативност, интересантан и разнолик живот, слободу, док физички неактивни млади више вреднују новац, односно богатство (Perenyi, 2010).

Вредности се могу мењати током живота, а могу зависити и од животне доби испитаника. Тако је опредељеност за универзалне вредности истраживана 2002. године над око 1.300 пунолетних испитаника у Војводини. Показало се да је здравље издвојено као највећа вредност, затим љубав и мир, а значајан број испитаника изабрао је вредности као што су слобода, бог и правда. Одређене варијабле као што су пол и године живота утицале су на избор, па се за здравље највише опредељује популација од 35 до 50 година живота, док су правда и мир најважнији испитаницима изнад 60 година. Женски пол се опредељује за здравље и бога, а мушки пол за правду и слободу. За љубав и мир се подједнако опредељује и мушки и женски пол. Породица као колективна вредност је најважније процењена. Породица је незнатно важнија женском полу, а домовина мушком полу. Породица је важнија испитаницима од 18 до 55 година старости, а домовина испитаницима преко 55 година живота. Када су у питању карактерне особине, највише се цени поштење, искреност, толерантност, одговорност, а најмање патриотизам, верност, марљивост (Koković i Lazar, 2004).

\section{2. Неки фактори моралног и вредносног усмеравања}

Важни фактори социјализације и креирања погледа на морал јесу школа и породица. Породица као несумњиво важан и примарни агенс социјализације 
утиче на развој моралних вредности, али је њена улога само примарна јер је личност под утицајем много фактора који обликују њен живот и стварају животни стил (Đorđević, 2002; Đorđević i Đorđević, 2007; Jevtić, 2012). Међутим, слободно време које млади све више упражњавају уз медије утиче на формирање вредности које могу јаче деловати на формирање ставова од школе и породице, што зависи од индивидуе и њеног васпитања. Волонтеризам као појава у друштву одраз је позитивних вредности и усмерења ка добробити других. У даљем тексту истичемо школу, слободно време, медије и волонтеризам као неке од фактора моралног и вредносног усмеравања.

\section{1. Морално васпитање у школи}

Када је школа као институција моралног и вредносног усмеравања у питању, акценат се ставља на међусобни однос њених актера, садржајима који се реализују и начинима њихове реализације. Од наставника се очекује да има изграђен систем вредности који је морално пожељан, јер је он модел ученицима.

Учење моралним вредностима поред садржаја подразумева и начине на који се наставници опходе према деци, као и стратегије које користе како би решили проблеме. У Финским школама постоји пракса решавања моралних дилема која води до изградње правих вредности, што је показала студија случаја. О моралним дилемама и њиховом решавању треба дискутовати на нивоу целе школе (Tirri, 1997). Истраживање ауторке Матејевић (2008) показало је да наставници основних школа у односима с ученицима преферирају аутономне вредности: одговорност, самосталност, радозналност, али је један део наставника показао и тенденцију ка конформизму. Аутономност не значи непостојање вредности. Од наставника се очекује да пропагира пожељне вредности, али не и да њима манипулише. Истраживање Јевтић (2011) показује да у школском систему Србије постоји тежња ка моралном усмеравању ученика кроз дискусију, развој аутономије и одсуство стереотипа. Наставници су свесни важности своје улоге у моралном васпитању, и истичу методу подстицања као значајну за развој пожељног понашања. Наставници се слажу да је неопходно развити адекватан програм моралног образовања, јер у Србији не постоји морално образовање као предмет, већ је на креативности наставника да кроз своје предмете пренесу ученицима моралне поуке и поруке, односно морално их васпитаваjу (Jevtić, 2014).

Јевтић и Јовановић (2018) истичу значај наставних садржаја за развој моралних вредности, односно усмереност ка просоцијалности, алтруизам и емпатичност. Показало се да ученици који похађају верску наставу показују алтруистичније понашање од ученика који похађају грађанско васпитање. Ученици су показали задовољавајући степен просоцијалног понашања, с импликацијама да је потребно да просоцијалност буде израженија.

Аутор Глетер (Glatter, 2017) осврће се на стање у образовању у Енглеској истичући да је школи потребна реформа. Школа треба да има своју моралну и социјалну сврху и управо моралне, социјалне и културне теме треба да пред- 
стављају „срце школе“. У школама треба више да буде заступљен плурализам и инклузивност, а мање наредба и конфронтација (Glatter, 2017: 118; 120; 122).

Наставник као модел понашања који делује на ученика чак и несвесно, мора свој посао обављати у складу са одређеним професионалним вредностима. Истраживање вредносних оријентација будућих учитеља и васпитача показало је да се високо вреднују породична сигурност, срећа и слобода, искрено пријатељство, унутрашња хармонија, самопоштовање (Bojović, 2017: 44). Етика у обављању посла наставника мора да постоји и да се поштује. У Јапану, морално образовање је саставни део курикулума. Породица је схваћена као продужена рука школе и самим тим се утицај моралних инструкција, односно морално вођење у школи повећава (Whitman, 1999). Наставник у свом иницијалном образовању мора да похађа неки вид програма о етици. У истраживању над 217 испитаника из Америке, Холандије, Енглеске, Канаде и Аустралије, који предају етику, и испитаника који нуде неки програм или курс о етици, показало се да је етика у иницијалном образовању наставника највише заступљена тема у Аустралији, а најмање у Енглеској (Maxwell, 2017).

Тенденција у свету је да друштво треба да буде демократско, а самим тим и његове институције. Уколико образовање и васпитање нису засновани на демократским вредностима, неће доприносити развоју демократије, већ могу довести и до краја таквих друштава. Фински аутор Полиматка (Puolimatka, 1990) истиче да је у школама потребно створити атмосферу где се цене вредности и особа поштује, како би се омогућило развијање правих вредности. Наставник не треба манипулисати вредностима, већ својом компетентношћу ученике водити кроз усвајање оних вредности које карактеришу демократско друштво.

\section{2. Слободно време и медији као креатори и катализатори вредности}

Један од адекватних начина сагледавања вредносних оријентација којима теже млади и одрасли јесте истраживање начина и квалитета провођења слободног времена. У савременом дигиталном друштву, највећи део свог времена проводимо уз медије. Утицај медија на децу, а поготову на децу раног узраста показало је и истраживање у Турској спроведено 2016. године, на узорку од 57 ученика трећег и четвртог разреда. Ученици телевизију сагледавају као забаву, као пријатеља. Мањи број ученика изнео је негативне ставове о утицају телевизије (Güven, 2017). Масовни медији имају своје позитивне и негативне утицаје. Задатак је породице и школе да усмерава и прати на који начин деца схватају оно што телевизија пласира. С друге стране, истраживање у Малезији скренуло је пажњу да се дигитална технологија може ставити у функцију развоја моралности. Приче које су намењене деци у себи носе одређену моралну поуку. Стављене у дигиталну функцију кроз игре, тестове, разне врсте софтвера, где постоји комбинација текста, слике, анимације, звука, брже и лакше се деца могу усмерити ка одређеним вредностима (Norhayati \& Siew, 2004). Истраживање спроведено над 212 ученика четвртог разреда основне школе је показало да се употреба образовних софтвера у настави допада ученицима и да би волели да у будућности имају 
више прилика да уче уз помоћ компјутера (Stanisavljević-Petrović i sar., 2015). На овај начин се могу ученицима презентовати разне теме, а комбинација аудио-визуелних садржаја доводи до бољег резновања.

За основношколски узраст је карактеристична окренутост вршњацима, што је показало и истраживање аутора Микановић (2013), где се показало да код ученика основне школе преовладавају социјалне вредности. Истраживање о положају и потребама младих у Србији $(2013 ; 2016)$ показало је да млади старији од 30 година волонтерске активности наводе као корисне активности, да се подстичу у породици и да су корисне за добијање посла. Слободно време испитаници од 15 до 30 година најчешће проводе са пријатељима, уз рачунар, а најмање са породицом.

Истраживање спроведено у Црној Гори над преко 500 испитаника узраста од 16 до 27 година, показало је да млади највећи део слободног времена проведу слушајући музику и гледајући телевизију, док на интернету проведу и до 4 сата. Највише се користи за забаву, али се такође учестало користи и за информисање и учење. Пријатељство, образовање, верност, одговорност, породица, каријера, спорт, независност, здравље, изглед, неке су од вредности које су доминантне у овој популацији. Код других људи највише се цени исправност, толеранција, достојанство, алтруизам, иновативност, борбеност, предузимљивост, друштвени углед, а најмање се цени материјално богатство. Највише се цени породица (Knežević i Đukanović, 2016).

Истраживање спроведено на популацији средњошколаца показало је да интернет њихов живот чини квалитетнијим, као и „да не чине насиље на интернету, да су опрезни на интернету, обазриви, не угрожавају сопствену и туђу безбедност, сматрају да на мрежи има и лажи и искрености“ (Jovanović i Kostadinović, 2019: 96). Путем мреже се пласирају одређене вредности и креирају вредносне оријентације. Нове генерације свој живот све више премештају у виртуелни простор зато је неопходно да се морално понашају и када комуницирају на мрежи.

\section{3. Волонтеризам као израз позитивних вредности}

Волонтерске активности као преференција чији је циљ да се другима несебично помогне, да се чини добро дело, а да циљ није новац сам по себи, истраживане су у периоду од 2003. до 2010. године у Мађарској, Румунији и Украјини на узорку преко 8.000 студената. Показало се да се тежња ка волонтеризму удвостручила у периоду од 2005. до 2010. године и код мушког и код женског пола. Од 2.384 студената, $26.10 \%$ се бави волонтерским активностима. Исти узорак је показао да се више волонтеризмом баве религиозни студенти. Неке вредности су изразито повезане са волонтеризмом: право пријатељство, пружање помоћи другима, чињење других срећнима. С друге стране, особе које уживају у животу и воле материјалну сигурност мање теже волонтеризму. Традиционални типови волонтерства као што су чланство у волонтерским организацијама и сакупљање добровољних прилога, популарнији су код студената женског пола, док су спортске, културне и политичке волонтерске активности популарније код студената мушког пола (Fényes \& Pusztai, 2012). 
Кроскултурна истраживања спроведена над 4.081 испитаником у Аустралији $(\mathrm{N}=609)$, Канади $(\mathrm{N}=974)$, Новом Зеланду $(\mathrm{N}=605)$, Енглеској $(\mathrm{N}=600)$ и Америци $(\mathrm{N}=1294)$ показују да су млади укључени у волонтерске активности, чак више од 70\% испитаника. Волонтеризам је највише заступљен у Канади, затим у Америци, Новом Зеланду, Енглеској и најмање у Аустралији. На целокупном узорку највећи број испитаника волонтира у активностима које се реализују са њиховим вршњацима, као ментори, саветници, тренери. Највише оваквих волонтера је у Канади, а најмање у Енглеској. Потом се истиче волонтеризам у спортским и културним активностима, који је најзаступљенији у Аустралији, а најмање заступљен на Новом Зеланду. Затим следе организације и универзитетски клубови, где се истиче Америка, а најмање је присутно на Новом Зеланду. У здравственим и хитним службама највише волонтирају испитаници из Америке, а најмање са Новог Зеланда. Волонтеризам у религиозним организацијама најзаступљенији је у Америци и Аустралији, а најмање заступљен у Енглеској. Волонтеризам у комшилуку или активистичким групама најзаступљенији је у Америци, а најмање заступљен у Енглеској. Питање које су истраживачи поставили је шта ученике и студенте мотивише на волонтеризам и у чему виде корист од ове врсте активности. Мотиви који покрећу појединце који волонтирају недељно, или неколико пута месечно јесу каријерни, односно како би ту активност укључили у своју биографију и тиме можда обезбедили запослење. Највећи број испитаника има алтруистичке преференције, односно волонтира како би се помогло другима. Велики број испитаника волонтира како би стекао нове пријатеље. Као корист од волонтеризма испитаници су највише наводили развијање лидерских вештина, али и каријеру и запослење, односно стицање искуства у послу, затим могућност да науче нове ствари, као и стварање социјалних контаката (Cnaan et al., 2010).

Како је корист од волонтеризма многострука, потребно је заговарати је у школи, породици и медијима. Бавећи се волонтерским радом појединац развија себе, помаже другима, квалитетно проводи своје слободно време.

\section{3. Доминантне вредности према налазима Светске студије вредности}

Пројекат Светска студија вредности (World Values Survey) покренут је како би се сагледале вредности које доминирају у свету. Ова студија започела је 1981. године и у њој учествује преко 100 земаља попуњавајући истоветни упитник. Омогућила је формирање веома корисне базе података о вредностима и вредносним оријентацијама људи широм света. Користећи ову базу података, где је упитнике попуњавало преко 1.000 испитаника из сваке земље појединачно, у периоду од 2010. до 2014. године, компаративном анализом могу се изнети следећи закључци о томе које вредности доминирају у одређеним државама, односно колико су важне у животима људи. Категорија за коју су сагледавани одговори је - веома важно (Inglehart et al., 2014a). 
Породица: државе у којима су се испитаници са преко 95\% изјаснили да им је породица веома важна јесу: Јерменија, Еквадор, Грузија, Гана, Јордан, Киргистан, Либија, Малезија, Мексико, Нигерија, Филипини, Катар, Зимбабве, Тунис, Турска, Египат, Узбекистан, Јемен, а најмање су ову категорију изабрали у Бахреину.

Пријатељство: Катар и Руанда су државе где се највише цени пријатељство, а државе у којима су се испитаници са преко 50\% изјашњавали да им је веома важно пријатељство као вредност су: Аргентина, Аустралија, Кипар, Естонија, Грузија, Немачка, Јордан, Кувајт, Либан, Либија, Нови Зеланд, Нигерија, Сингапур, Шведска, Турска, Египат, Америка, Уругвај, Узбекистан. Испитаници из Румуније су се најмање опредељивали за категорију веома важно.

Слободно време: са преко 50\%, ову вредност у категорији веома важно процениле су: Чиле, Кипар, Еквадор, Гана, Нигерија, Шведска, Тринидад и Тобаго, а најмање вредности овој категорији придали су Филипини.

Политика: као веома важна ова вредност се показала за Тајланд са $32 \%$, а најмање се испитаника определило за ову категорију у Словенији, са $2 \%$.

Посао: најзначајнији је људима у Гани, а најмање се за категорију веома важно определила Холандија. Са мање од 50\% изјаснило се 14 од 60 земаља.

Религија: најважнија је у животима људи из Катра, Јемена, Туниса, Либије, Египта, Јордана, Гане, Алжира са преко 90\%, а најмање су се за ову категорију определили људи из Кине.

Демократска држава: Шведска са 73.5\% је држава у којој је људима најважније да живе у демократији, док је у Бахреину то најмање важно. Земље које су се са преко 50\% изјасниле да им је демократска држава веома важна су: Аустралија, Јерменија, Тајван, Кипар, Грузија, Немачка, Либија, Мексико, Нови Зеланд, Пољска, Катар, Румунија, Зимбабве, Тринидад и Тобаго, Тунис, Уругвај, Узбекистан. Најмање је важна Индији (Inglehart et al., 2014a).

На основу изнетих резултата може се закључити да је породица као универзална вредност најважнија у животима људи, док се политици као вредности не приписује веома велика важност. У односу на период од 2005. до 2009. године не постоје нека значајнија одступања у поимању ових универзалних вредности. Показало се да је значајност демократије опала (Inglehart et al., 2014b).

Резултати испитивања осталих вредности су показали следећу опредељеност: Креативност: најважнија је људима у Нигерији, 52.8\%, а најмање важна у Индији, са $13.1 \%$; Богатство: најважније је људима у Нигерији са $29.8 \%$, а 46.8\% људи у Мексику се изјаснило да им је најмање важно; Cигурност: најважнија је људима са Катра, са 66.9\%, а најмање важном проценило је $12.3 \%$ људи из Аргентине; Забава: најзначајнија је у Катру са 43.7\%, а најмање значајна у Руанди 39.7\%; Чинити добро дело за друштво: најважније је у Катру и Либији са преко 50\%, а најмање важно у Азербејџану са 6.2\%; Помагати ближғима: са преко $50 \%$ је значајно у Либији, а најмање је значајно у Индији, са 7.9\%; Бити успешан/постигнуће: најзначајније је у Катру са $60.8 \%$, а најмање значајно у Уругвају са $22.5 \%$; Авантуристички, узбудљив живот: најзначајнији је у Нигерији са $27.7 \%$, а најмање значајан на Тајвану са $46.2 \%$; Учтиво понашање: најзначајније је у Либији са $54.7 \%$, а најмање значајно у Ја- 
пану са 22.5\%; Брига за природу и окружење: најзначајније је у Катру са $61.2 \%$, а најмање значајно у Руанди са $14.4 \%$; Традищија: најзначајнија је у Катру са $78.2 \%$ а најмање значајна у Холандији са $25.1 \%$; Оно што се примећује је да се у Катру, земљи Блиског истока, испитаници изразито опредељују, односно са највећом важношћу процењују животне вредности (Inglehart et al., 2014a).

\section{Закључак}

На један широк и комплексан начин сагледали смо вредносна усмерења која су заступљена у свету који нас окружује. С обзиром да је немогуће мапирати један јединствен систем вредности, морално пожељног понашања јер се он разликује од друштва и културе, нећемо доносити закључке шта би било морално добро, шта оно јесте данас и којим вредностима треба тежити. Вредности су широка категорија, а варијабли са којима се могу укрстити је такође много. Може се констатовати шта је највише заступљено у теоријским и истраживачким студијама широм света, односно које су тенденције у мерењу вредносних преференција.

Породица, пријатељство, алтруизам, успостављање социјалних контаката, сигуран посао, самоактуелизација, здравље, љубав, вера, сигурност, самосталност, колективизам, слобода, мир, поштење, искреност, толерантност, верност, одговорност, сарадња су неке од вредности које су важне. Окренутост ка волонтеризму у свету расте, што због тежње да се чини добро дело, што због социјалних контаката који се на тај начин остварују, као и квалитетнијег провођења слободног времена.

Млади људи виде значај у волонтеризму и алтруизму, цене пријатељство, породицу, вреднују здравље. Потребно је искористити образовну функцију медија, и радити на формалном моралном образовању. На основу изнетих резултата истраживања произилазе многа проблемска питања која треба истраживати на репрезентативном узорку, с циљем сазнања да ли се вредности мењају током живота, да ли се разликују у односу на узраст или смену генерација, социоекономски статус и друге факторе.

\section{Литература}

Bojović, Ž. (2017). Terminalne vrednosti-životni ciljevi-perspektiva studenata budućih učitelja i vaspitača. Inovacije u nastavi, 30(4), 35-48.

Budimir-Ninković, G. (2008) Potrebe i mogućnosti istraživanja vrednosnih orijentacija učenika osnovne škole. Inovacije u nastavi, 21(2), 21-28.

Cnaan, A. R., Smith, A. K., Holmes, K., Haski-Leventhal, D., Handy, F. \& Brudney, L. J. (2010). Motivations and Benefts of Student Volunteering: Comparing Regular, Occasional, and Non-Volunteers in Five Countries. Retrieved (17.07.2018) from: http://repository.upenn.edu/spp_papers/153 
Collinson, V., Killeavy, M. \& Stephenson, H. J. (2008). Exemplary Teachers: Practicing an Ethic of Care in England, Ireland, and the United States. Annual Meeting of the American Educational Research Association. Retrived (16.07.2018) from: https:// files.eric.ed.gov/fulltext/ED423217.pdf

Čekrlija, Đ., Turjačanin, V. i Puhalo, S. (2004). Društvene orijentacije mladih. Banja Luka: Nacionalni institut za borbu protiv narkomanije.

Dević, I., Majetić, F. i Krnić, R. (2015). Vrijednosne preferencije hrvatskih građana kao odrednice materijalizma. Društvena istraživanja: časopis za opća društvena pitanja, 24(4), 555-576. doi: 10.5559/di.24.4.05

Dunjić-Mandić, K. i Karanac, R. (2017). Preferencije društvenih ciljeva učenika gimnazije. U: Veljović, A. (ur.) Zbornik radova - Informacione tehnologije, obrazovanje $i$ preduzetništvo ITOP17 (467-474). Čačak: Fakultet tehničkih nauka.

Đorđević, J. (2002). Moralno vaspitanje - teorija i praksa, 2. izdanje. Novi Sad: Savez pedagoških društava Vojvodine; Viša škola za obrazovanje vaspitača.

Đorđević, B. i Đorđević, J. (2007). Savremeni problemi društveno-moralnog vaspitanja. Novi Sad: Savez pedagoških društava Vojvodine.

Fényes, H. \& Pusztai, G. (2012). Volunteering Among Higher Education Students. Focusing on the Micro-level Factors. Journal of Social Research \& Policy, 3(1), 73-95.

Franc, R., Šakić, V. i Ivičić, I. (2002). Vrednote i vrijednosne orijentacije adolescenata: hijerarhija i povezanost sa stavovima i ponašanjima. Društvena istraživanja: časopis za opća društvena pitanja, 11(2-3), 215-238.

Glatter, R. (2017). 'Because we can': Pluralism and Structural Reform in Education. London Review of Education, 15(1), 115-126. doi: 10.18546/LRE.15.1.10

Güven, S. (2017). Determination of the Perceptions of Primary School Students Regarding the Concept of Television. Journal of Education and Training Studies, 5(8), 151-166. doi:10.11114/jets.v5i8.2554

Havelka, N. (1998). Vrednosne orijentacije adolescenata: vrednosti i kontekst. Psihologiija, 4, 343-364.

Inglehart, R., C. Haerpfer, A. Moreno, C. Welzel, K. Kizilova, J. Diez-Medrano, M. Lagos, P. Norris, E. Ponarin \& B. Puranen et al. (eds.) (2014a). World Values Survey: Round Six - Country-Pooled Datafile Version: http://www.worldvaluessurvey.org/ WVSDocumentationWV6.jsp Madrid: JD Systems Institute.

Inglehart, R., C. Haerpfer, A. Moreno, C. Welzel, K. Kizilova, J. Diez-Medrano, M. Lagos, P. Norris, E. Ponarin \& B. Puranen et al. (eds.) (2014b). World Values Survey: Round Five - Country-Pooled Datafile Version: http://www.worldvaluessurvey.org/ WVSDocumentationWV5.jsp Madrid: JD Systems Institute.

Ilišin, V. i Gvozdanović, A. (2016). Struktura i dinamika vrijednosti mladih u Hrvatskoj. U: Sekulić, D. (ur.) Vrijednosti u Hrvatskom društvu (169-197). Zagreb: Centar za demokraciju i pravo Miko Tripalo.

Istraživanje o položaju i potrebama mladih. (2013). Ministarstvo omladine i sporta Republike Srbije. Retrived (19.07.2018.) from: http://www.mos.gov.rs/mladisuzakon/attachments/ article/387/Istrazivanje\%20polozaj\%20i\%20potrebe\%20mladih\%20-\%202013.pdf

Istraživanje položaja i potreba mladih u Republici Srbiji. (2016). Ministarstvo omladine i sporta Republike Srbije. Retrived (19.07.2018) from: http://www.mos.gov.rs/ 
public/ck/uploads/files/Dokumenta/Omladina/istrazivanja/istrazivanje\%202016/ Istrazivanje $\% 20$ polozaja $\% 20 \mathrm{i} \% 20$ potreba $\% 20$ mladih $\% 20$ teren $\% 20$ decembar $\% 20$ 2016.pdf

Javno mnjenje Srbije - politički aktivizam građana Srbije. (2017). CeSID. Retrived (17.07.2018) http://www.cesid.rs/wp-content/uploads/2017/06/POLITI\%C4\%8CKIAKTIVIZAM-GRA\%C4\%90ANA-SRBIJE-2017.pdf

Jevtić, B. (2011). Pedagogical Function of Teachers in Developing Moral Values of Children and Adolescents. Practice and Theory in Systems of Education, 6(2), 167-176.

Jevtić, B. (2012). Pedagogija moralnosti. Niš: Filozofski fakultet.

Jevtić, B. (2014). Teachers' Pedagogical Actions Affecting the Moral Development of Personality. Problems of Education in the 21st Century, 58, 67-81.

Jevtić, B. i Jovanović, A. (2018). Razvijanje prosocijalnosti u nastavi veronauke i građanskog vaspitanja. Naša škola, 24(2), 29-49. doi: 10.7251/NSK1802029J

Joksimović, S. i Maksić, S. (2006). Vrednosne orijentacije adolescenata: usmerenost prema sopstvenoj dobrobiti i dobrobiti drugih. Zbornik Instituta za pedagoška istraživanja, 38(2), 415-429. doi: 10.2298/ZIPI0602415J

Jovanović, A. i Kostadinović, M. (2019). Digitalna kompetentnost adolsecenata. Godišnjak za pedagogiju, 4(1), 85-100. doi: 10.46630/gped.1.2019.06

Knežević, M. i Đukanović, P. (2016). Mladi - društveni dekor ili društveni kapital? Podgorica: Centar za građansko obrazovanje CGO.

Koković, D. i Lazar, Ž.(2004). Društvena tranzicija i promene u sistemu vrednosti: primer Vojvodine. Sociološki preged, 38(1-2), 249-265.

Kuzmanović, B. i Petrović, N. (2009). Preferencije ličnih i društvenih ciljeva srednjoškolaca Srbije. Sociološki preged, 43(4), 503-523.

Matejević, M. (2008). Vrednosne orijentacije nastavnika. Inovacije u nastavi, 21(2), 29-38.

Maxwell, B. (2017). Codes of Professional Conduct and Ethics Education for Future Teachers. Philosophical Inquiry in Education, 24(4), 323-347.

Mikanović, B. (2013). Vrednosne orijentacije učenika u slobodnom vremenu. Sinteze, 4, 53-69.

Mladenović, U. i Knebl, J. (2000). Vrednosne orijentacije i preferencije životnih stilova adolescenata. Psihologija, 3-4, 435-454.

Norhayati, A. M., \& Siew P. H. (2004). Malaysian Perspective: Designing Interactive Multimedia Learning Environment for Moral Values Education. Educational Technology \& Society, 7(4), 143-152.

Perenyi, S. (2010). Human values of sport participant and non-participant Hungarian youth. Retrived (19.07.2018) from: https://pdfs.semanticscholar.org/b8b9/e8afaed35 335ff0a72c743eb6015a3f5da58.pdf

Petrović, J. i Zotović, M. (2012). Adolescenti u Srbiji: u traganju za novim vrednostima. Teme, 36(1), 47-66.

Pešić, J. (2006). Persistence of Traditionalist Value Orientations in Serbia. Sociologija, 47(4), 289-307.

Puolimatka, T. (1990). Pluralism and Education in Values. Research Bulletin 74. Finland, Helsinki: Department of Education, University of Helsinki. Retrived (18.07.2018) from: https://files.eric.ed.gov/fulltext/ED406244.pdf 
Radoman, M. (2011). Stavovi i vrednosne orijentacije srednjoškolca u Srbiji. Beograd: Helsinški odbor za ljudska prava.

Schwartz, H. S. (2012). An Overview of the Schwartz Teory of Basic Values. Online Readings in Psychology and Culture, 2(1). doi: 10.9707/2307-0919.1116

Stanisavljević-Petrović, Z., Stanković, Z. \& Jevtić, B. (2015). Implementation of Educational Software in Classrooms - Pupils' Perspective. Procedia - Social and Behavioral Sciences, 186, 549-559. doi: 10.1016/j.sbspro.2015.04.131

Tirri, K. (1997). How Finnish Teachers Identify and Solve Moral Dilemmas at School: A Case Study. Annual Meeting of the American Educational Research Association. Retrived (18.07.2018.) from: https://files.eric.ed.gov/fulltext/ED418906.pdf

Whitman, C. N. (1999). The Japanese Middle Schools: A Reflection on Practices, Issues and Trends. Japan-United States Teacher Education Consortium Conference, Honolulu, Hawaii. Retrived (18.07.2018.) from: https://files.eric.ed.gov/fulltext/ED434094.pdf

\title{
DOMINANT VALUE ORIENTATIONS AND FACTORS OF VALUE ORIENTATION OF YOUTH
}

\author{
Bisera Jevtić \\ University of Nis, Faculty of Philosophy, Department of Pedagogy \\ Aleksandra Jovanović \\ University of Nis, Faculty of Philosophy, Department of Pedagogy,
}

(PhD student)

\begin{abstract}
Summary: The aim of this paper is to point to the descriptors of value systems that exist in society, in Serbia as well as in other countries. Outlooks on morals and values sought to be brought closer, with the analysis of the results of research and pedagogical implications of authors across the world, primarily in students. It is aspired to discover which values dominate, that is, what are lifestyles of contemporary society. With the discussion on morals, values, a summed review of value preferences is given. It can be concluded that the same universal values prevail. Value pluralism is represented. Family is the most important value in people's lives. The school is an institution of moral and value orientation in which the relationship of mutual respect should be emphasized. The pursuit of altruism and volunteerism is a reflection of positive attitudes and a desire to help others. Media have a significant role in forming values and it is necessary to use their educational function. Free time is also a significant segment in which one can influence forming values, and it is necessary to organize it with the aim of own development.
\end{abstract}

Key words: values, value orientations, moral education, value guidance factors.

\section{Citiranje članka:}

Jevtić, B. i Jovanović, A. (2020). Dominantne vrednosne orijentacije i faktori vrednosnog usmeravanja mladih. Godišnjak za pedagogiju, 5(2), 7-20. 